\title{
Front Matter: Volume 10442
}

, "Front Matter: Volume 10442," Proc. SPIE 10442, Quantum Information Science and Technology III, 1044201 (29 November 2017); doi: $10.1117 / 12.2302601$

SPIE. Event: SPIE Security + Defence, 2017, Warsaw, Poland 


\title{
PROCEEDINGS OF SPIE
}

\section{Quantum Information Science and Technology III}

\author{
Mark T. Gruneisen \\ Miloslav Dusek \\ John G. Rarity \\ Editors
}

13-14 September 2017

Warsaw, Poland

Sponsored by

SPIE

Cooperating Organisations

CENSIS: Innovation Centre for Sensor \& Imaging Systems (United Kingdom)

Polish Technological Platform on Photonics (Poland)

MIRPHAB (France)

Photonics Society of Poland (Poland)

Cranfield University (United Kingdom)

Published by

SPIE 
The papers in this volume were part of the technical conference cited on the cover and title page. Papers were selected and subject to review by the editors and conference program committee. Some conference presentations may not be available for publication. Additional papers and presentation recordings may be available online in the SPIE Digital Library at SPIEDigitalLibrary.org.

The papers reflect the work and thoughts of the authors and are published herein as submitted. The publisher is not responsible for the validity of the information or for any outcomes resulting from reliance thereon.

Please use the following format to cite material from these proceedings:

Author(s), "Title of Paper," in Quantum Information Science and Technology III, edited by Mark T. Gruneisen, Miloslav Dusek, John G. Rarity, Proceedings of SPIE Vol. 10442 (SPIE, Bellingham, WA, 2017) Seven-digit Article CID Number.

ISSN: 0277-786X

ISSN: 1996-756X (electronic)

ISBN: 9781510613485

ISBN: 9781510613492 (electronic)

Published by

SPIE

P.O. Box 10, Bellingham, Washington $98227-0010$ USA

Telephone +1 3606763290 (Pacific Time) · Fax +1 3606471445

SPIE.org

Copyright (c) 2017, Society of Photo-Optical Instrumentation Engineers.

Copying of material in this book for internal or personal use, or for the internal or personal use of specific clients, beyond the fair use provisions granted by the U.S. Copyright Law is authorized by SPIE subject to payment of copying fees. The Transactional Reporting Service base fee for this volume is $\$ 18.00$ per article (or portion thereof), which should be paid directly to the Copyright Clearance Center (CCC), 222 Rosewood Drive, Danvers, MA 01923. Payment may also be made electronically through CCC Online at copyright.com. Other copying for republication, resale, advertising or promotion, or any form of systematic or multiple reproduction of any material in this book is prohibited except with permission in writing from the publisher. The CCC fee code is 0277$786 \mathrm{X} / 17 / \$ 18.00$.

Printed in the United States of America.

Publication of record for individual papers is online in the SPIE Digital Library.

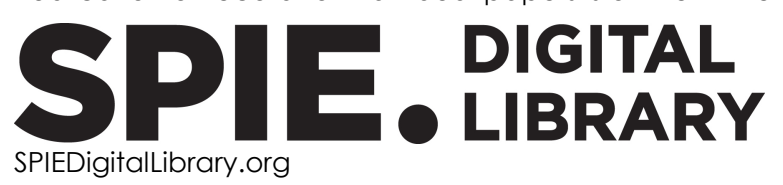

Paper Numbering: Proceedings of SPIE follow an e-First publication model. A unique citation identifier (CID) number is assigned to each article at the time of publication. Utilization of CIDs allows articles to be fully citable as soon as they are published online, and connects the same identifier to all online and print versions of the publication. SPIE uses a seven-digit CID article numbering system structured as follows:

- The first five digits correspond to the SPIE volume number.

- The last two digits indicate publication order within the volume using a Base 36 numbering system employing both numerals and letters. These two-number sets start with 00, 01, 02, 03, 04, 05, 06, 07, 08, 09, 0A, OB ... 0Z, followed by 10-1Z, 20-2Z, etc. The CID Number appears on each page of the manuscript. 


\title{
Contents
}

\author{
$\checkmark$ Authors \\ vii Conference Committee
}

RANDOMNESS, QUANTUM ALGORITHMS, AND SECURITY PROOFS

1044203 On problems in security of quantum key distribution raised by Yuen [10442-3]

QUANTUM ENTANGLEMENT: FROM FUNDAMENTAL PHYSICS TO APPLICATIONS

1044204 A significant-loophole-free test of Bell's theorem with entangled photons (Invited Paper) [10442-4]

QUANTUM KEY DISTRIBUTION

1044208 Approaches to a global quantum key distribution network (Invited Paper) [10442-7]

1044209 Enhancing implementation security of QKD (Invited Paper) [10442-8]

10442 OA A flexible continuous-variable QKD system using off-the-shelf components [10442-9]

10442 OB Multimode entanglement assisted QKD through a free-space maritime channel [10442-10]

QUANTUM COMMUNICATION

10442 OE Modeling satellite-Earth quantum channel downlinks with adaptive-optics coupling to single-mode fibers [10442-13]

10442 OF Modeling a space-based quantum link that includes an adaptive optics system [10442-14]

JOINT SESSION II: COMPONENTS AND TECHNOLOGIES FOR QUANTUM DEVICES

10442 OK Integrated photon sources for quantum information science applications [10442-18]

$10442 \mathrm{OL}$ Setting best practice criteria for self-differencing avalanche photodiodes in quantum key distribution (Best Student Paper Award) [10442-19]

10442 OM Nonlinear processes in lossy microring resonators [10442-20]

10442 ON GaN laser diodes for quantum technologies [10442-21] 
1044200 Tapered waveguide high power AIGalnN laser diodes and amplifiers for optical integration and quantum technologies [10442-22]

Proc. of SPIE Vol. 10442 1044201-4

Downloaded From: https://www.spiedigitallibrary.org/conference-proceedings-of-spie on 26 Apr 2023 Terms of Use: https://www.spiedigitallibrary.org/terms-of-use 


\title{
Authors
}

Numbers in the index correspond to the last two digits of the seven-digit citation identifier (CID) article numbering system used in Proceedings of SPIE. The first five digits reflect the volume number. Base 36 numbering is employed for the last two digits and indicates the order of articles within the volume. Numbers start with 00, 01, 02, 03, 04, 05, 06, 07, 08, 09, 0A, 0B...0Z, followed by 10-1Z, 20-2Z, etc.

\author{
Abellán, Carlos, 04 \\ Alsing, P. M., OK, OM \\ Amaya, Waldimar, 04 \\ Bedington, Robert, 08 \\ Bettelli, Stefano, OA \\ Beyer, Jörn, 04 \\ Brunner, Hans H., OA \\ Comandar, Lucian C., OA \\ Czernecki, R., ON, $0 \mathrm{O}$ \\ Djordjevic, Ivan B., OB \\ Duchane, Alexander W., OF \\ Dynes, James F., OL \\ Englund, D. R., OK \\ Fanto, M. L., OK \\ Flanagan, Michael B, OE \\ Fung, Fred, OA \\ Gariano, John, OB \\ Gerrits, Thomas, 04 \\ Gibasiewicz, K., 00 \\ Giustina, Marissa, 04 \\ Gruneisen, Mark T., OE \\ Grzanka, S., 00 \\ Hach, E. E., OM \\ Handsteiner, Johannes, 04 \\ Hillerkuss, David, OA \\ Hochrainer, Armin, 04 \\ Hodson, Douglas D., OF \\ Islam, Tanvirul, 08 \\ Iwakoshi, T., 03 \\ Kafar, A., 00 \\ Karinou, Fotini, OA \\ Koehler-Sidki, Alexander, OL \\ Kofler, Johannes, 04 \\ Kuschnerov, Maxim, OA \\ Larsson, Jan-Åke, 04 \\ Leszczyński, M., ON, 00 \\ Ling, Alexander, 08 \\ Lita, Adriana E., 04 \\ LU, T., OK \\ Lucamarini, Marco, OL \\ Mailloux, Logan O., OF \\ Marona, L., ON, 00 \\ Mikroulis, Spiros, OA \\ Mitchell, Morgan W., 04 \\ Mogent, N. A., OK \\ Najda, S. P., ON, $0 O$ \\ Nam, Sae Woo, 04 \\ Peev, Momtchil, OA \\ Perlin, P., ON, $0 O$
}

\author{
Phelan, Kevin, 04 \\ Poppe, Andreas, OA \\ Preble, S. F., OK \\ Rizzo, A., OK \\ Roberts, George L., OL \\ Savory, Seb J., OL \\ Scheidl, Thomas, 04 \\ Schiavon, D., ON, 00 \\ Shalm, Lynden K., 04 \\ Sharpe, Andrew W., OL \\ Shields, Andrew J., OL \\ Sickmiller, Brett A, OE \\ Stanczyk, S., ON, 00 \\ Steidle, J. A., OK \\ Steinlechner, Fabian, 04 \\ Suski, T., ON, 00 \\ Tamaki, Kiyoshi, 09 \\ Thomas, P. M., OK \\ Tison, C. C., OK \\ Ursin, Rupert, 04 \\ Versteegh, Marijn A. M., 04 \\ Wang, Dawei, OA \\ Wang, Z., OK \\ Wengerowsky, Sören, 04 \\ Wisniewski, P., ON \\ Wisniewski, P., 00 \\ Wittmann, Bernhard, 04 \\ Xie, Changsong, $0 \mathrm{~A}$ \\ Yuan, Zhiliang, OL \\ Zeilinger, Anton, 04
}


Proc. of SPIE Vol. 10442 1044201-6

Downloaded From: https://www.spiedigitallibrary.org/conference-proceedings-of-spie on 26 Apr 2023 Terms of Use: https://www.spiedigitallibrary.org/terms-of-use 


\section{Conference Committee}

Symposium Chair

Ric Schleijpen, TNO Defence, Security and Safety (Netherlands)

Symposium Co-Chairs

Karin Stein, Fraunhofer Institute of Optronics, System Technologies and Image Exploitation IOSB (Germany)

Jan K. Jabczyński, Military University of Technology (Poland)

Conference Chairs

Mark T. Gruneisen, Air Force Research Laboratory (United States)

Miloslav Dusek, Palacký University, Olomouc (Czech Republic)

John G. Rarity, University of Bristol (United Kingdom)

Conference Program Committee

Paul M. Alsing, Air Force Research Laboratory (United States)

Konrad Banaszek, University of Warsaw (Poland)

Jan Bouda, Masaryk University (Czech Republic)

Robert W. Boyd, University of Ottawa (Canada)

Gerald S. Buller, Heriot-Watt University (United Kingdom)

Ryan M. Camacho, Sandia National Laboratories (United States)

Marcos Curty, Universidade de Vigo (Spain)

Michael L. Fanto, Air Force Research Laboratory (United States)

John D. Gonglewski, European Office of Aerospace Research and Development (United Kingdom)

Gregory S. Kanter, NuCrypt LLC (United States)

Prem Kumar, Northwestern University (United States)

Norbert Lütkenhaus, University of Waterloo (Canada)

Vadim V. Makarov, University of Waterloo (Canada)

Ronald E. Meyers, U.S. Army Research Laboratory (United States)

Momtchil Peev, Austrian Research Centers GmbH - ARC (Austria)

Renato Renner, ETH Zürich (Switzerland)

Andrew J. Shields, Toshiba Research Europe Ltd. (United Kingdom)

Rupert Ursin, Austrian Academy of Sciences (Austria) 
Proc. of SPIE Vol. 10442 1044201-8

Downloaded From: https://www.spiedigitallibrary.org/conference-proceedings-of-spie on 26 Apr 2023 Terms of Use: https://www.spiedigitallibrary.org/terms-of-use 